\title{
Relationship between Bank Credit and Economic Growth: Evidence from Jordan
}

\author{
Izz Eddien N. Ananzeh ${ }^{1}$ \\ ${ }^{1}$ Faculty of Administrative and Financial Sciences, Philadelphia University, Amman, Jordan \\ Correspondence: Izz Eddien N. Ananzeh, Assistant Professor, Faculty of Administrative and Financial Sciences, \\ Philadelphia University, Amman, Jordan.
}

Received: December 30, 2015

Accepted: January 15, 2016

Online Published: March 8, 2016

doi:10.5430/ijfr.v7n2p53

URL: http://dx.doi.org/10.5430/ijfr.v7n2p53

\begin{abstract}
Despite the growing literatures that examined the relationship between financial developments and growth of any economy, there is scarceness in the empirical studies that examine the influence of bank credit on economic performance or growth at secrotal level of any country. Therefore this study came to examine the relationship between bank credit and economic growth in Jordan at different sectors for the period that span from 1993 to 2014. We employ two different methodologies Vector Error Correction Model (VECM) and Granger Causality Test,

The results report for a long run relationship could be inferred between Real GDP, and its Explanatory variables of Total Bank Credit (TBC); Bank Credit for Agriculture sector (CFA); Bank Credit for Industry sector (CFI); Bank Credit for Construction sector (CFC); Bank Credit for Tourism sector(CFT). So we can suggest that TBC, CFA, CFI, $\mathrm{CFC}$, and CFT are in the long term relationship with the development of Jordanian economy.

Granger causality test conclude for a causal relationship going from economic growth to bank credit at agriculture and construction sectors in Jordan economy. Also the results report bidirectional causality observed among economic development and bank credit to construction sector that is the most important sectors in this economy. Moreover, our results point out that the efficiency of the bank credit facilities in a major economic sectors has an important role in the Jordanian economic growth, and shows the needs to enhance the role of financial sector for different economic sectors by adopting more appropriate macroeconomic policies.
\end{abstract}

Keywords: bank credit, economic growth, (VAR) model, Vector Error Correction Model (VECM)

\section{Introduction}

The major portion of the financial literature point out that financial institution development should lead to the development of any economy. The relationship between development of financial sector and the economic growth firstly presented through work of Schumpeter (1911). He confirmed that the services provided by financial institutions could stimulate technological innovation and economic growth by funding productive investments.

The different people from different sector and different organization require financing for many purposes. The financial services provided the finance from different financial institutions that are divided into capital and money markets. we have commercial banks in the money markets that provide financial services, and his basic role involves taking funds from the surplus unit who have no instant needs to the deficit units, or may be in form of credit to investors who have smart ideas but lack the necessary funds to implement the ideas to create additional wealth.

Due to the rapid development of mankind all over the world the economic development occupied crucial role, and that increasing with time in order to raising the level of the peoples economically and socially. In the terms of economic development the development of financial sector, especially the bank credit play a vital important role to provide the necessary financial resources to finance various economic activities, and re-directing it to serve the economic sectors in correct way. There is many believes the changes in the volume of credit has a significant impact on Level of economic activity in terms of prosperity or deflation.

Potential positive connection between economic growth and the credit markets is evident to some extent because the developed countries without exception have the most advanced credit markets. 
There are various views about the causality relationship between financial intermediation and the growth of any economy. Many explanations have been offered empirically for this causality relationship and its causality direction. Bayoumi and Melander (2008) in his seminal work found when overall credit decreased by $2.5 \%$ causes the level of GDP to be decreased by $1.5 \%$, Similarly Demetriades and Hussein (1996) reported the same outcomes.

The prior findings in the financial literature have made it useful to investigate whether bank credits in our country can be depending on to motivate the growth of the Jordan economy or not. So that our study came to investigate the contribution of banks credit in Jordan for different sectors on economic growth through using different models to explore the role of the bank credit in the process of generating the growth, and based upon historical data we inspect the effectiveness of bank sector and the causality direction

A significant part of credit in Jordan is spread through the banking system, although there are some other institution, for example micro finance institutions, finance companies, and credit cooperative societies that provide credit for small projects. However, the data availability for these kind institutions is very limited.

The rest of this paper: Section 2 present literature review, Section 3 report the data and methodology used in this study, the empirical analysis results discussed in section 4, and finally Section 5 report the conclusion of our study.

\section{Literature Review}

The relationship between development of financial sector and the economic growth firstly presented through work of Schumpeter (1911). He confirmed that the services provided by financial institutions could stimulate technological innovation and economic growth by funding productive investments. In the same line, Robinson (1952); Shaw (1967); Goldsmith (1969); Gurly and Shaw (1973); and Spellman (1982) have contended that financial development could enhance the economic growth by increasing saving, improving the efficiency of allocation fund, and promoting capital accumulation.

Robinson, (1952), and Gurley and Shaw $(1960,1967)$ reported that financial development promotes the growth of economy. Also, the King and Levine (1993) reported that the development of financial markets mostly follows economic growth rate.

Financial literature was grown in recent years through many empirical studies by examining the role of financial intermediaries on economic growth, and employing many advanced methodologies that have shown the bank credit has positive impact on economic growth. Demetriades and Hussein (1996) examine the direction of causality between economic growth and financing sector development which covered sixteen developing countries, and the results of this study proof that the financing is a major factor in the economic growth.

Kar and Pentecost, (2000) employed VECM beside Graner-Causality test to examine the relation between these two issues, and they found that the causality direction running from financial development to growth of economy.

Baliamoune-Lutz (2008) discusses the relationship between financial development with four economic ratios and real output for the sample which covered three countries from North Africa: Egypt, Algeria, and Morocco for the period span from 1960 to 2001. They employ the methodology of VECM, and Co-integration to inspect the relationship. The results present that the financial development will leads economic growth.

Eatzaz and Malik (2009) investigate role of the of financial development on the growth of economy for the sample which covered thirty five developing countries through using GMM approach, and concluded if the domestic bank credit to the private sector increased this will lead increasing per workers output (productivity of workers) and consequently in the long increasing the economic growth.

Kar et al. (2011) investigate the causal between these two issues in the fifteen countries from MENA markets, and the period span from 1980 to 20007 . The study employed the panel causality testing approach, and the results suggest that is no clear cut on causality direction between two variable and different from country to another. Ben Salem and Trabelsi (2012) examine the relationship for the same issue in seven countries from southern Mediterranean countries during the period span from 1970 to 2006. The study applies the Pedroni panel co integration analysis for seven variable measure financial developments. The result of this paper confirms the presence of relationship with a long- rub base between the financial development and the rate of growth.

Depending upon the outcomes of previous literatures review, our contribution or the importance of our study came from many points. Firstly we investigate the relationship between bank credit at the sectoral country level which covered five sectors (agriculture, industry, construction, and tourism) Secondly we employed more Advance econometric techniques for example Vector autoregressive Approach (VAR) Model, and Granger Causality test. 
Thirdly our study covered Jordan market which is one of the very important markets in the middle east for a long period span from 1993 to 2014 at quarterly base.

\section{Data and Methodology}

\subsection{Data}

Sample period of our study spans from Dec 1993 to Dec 2014, and the study was carried out by using 85 quarterly observations, the time series data taken from Statistical Bulletin of Jordan Central Bank (CBJ).

The data used in this study includes:

1. The Real Gross Domestic Product (RGDP) at current basic price refers to the economic growth as dependent variable.

2. This article uses five independent variables that represent financial development:

- Total bank credit facilities for all sectors (TBC).

- Bank credit facilities for agriculture sector (CFA).

- Bank credit facilities for industry sector (CFI).

- Bank credit facilities for construction sector (CFC).

- Bank credit facilities for tourism sector (CFT).

Those five indicators refer to the efficiency of the banking system to generate finance lead to growth.

\subsection{Methodology}

The previous empirical evidence has agreed upon the existence of a relationship between bank credit and growth of the economy. In order to investigate this relationship we employed several analytical approaches.

Firstly, we will use econometrics methods which are used in the literatures to test the independence of all-time series.

\subsubsection{Unit Root Tests}

The most popular procedures that developed for testing the order of integration for the time series under consideration, we used two unit root tests :( parametric) the Augmented Dickey-Fuller (1979), and (nonparametric) Phillips-Peron (PP) unit root test (1988). Firstly ADF test is based on the estimation on the following formula:

$$
\Delta Y_{t}=\alpha_{0}+\alpha_{1} Y_{t-1}+\alpha_{2} T+\sum_{i=1}^{n} \beta_{i} \Delta Y_{t-i}+\gamma_{t}
$$

Where $Y_{t}$ refer to the time series under study; $\mathrm{t}=$ time trend; $\Delta=$ first difference operator; $\gamma_{t}=$ stationary stochastic process. Phillips and Perron (1987) made a modification for ADF $t$-statistic with $Z_{t}$ statistic; the null hypotheses $H O: \alpha_{1}=0$ against $H 1: \alpha_{1} \neq 0$ this mean a unit root exist:

$$
\Delta Y^{2}{ }_{t}=\delta \Delta Y_{t-1}+\sum_{t=1}^{q} \beta_{i} \Delta^{2}\left(Y_{t-1}\right)+\varepsilon_{t}
$$

Where $\Delta^{2}$ represent the second- difference operator, $\varepsilon_{t}$ represent the stationary stochastic process.ADF and PP tests are applied to last two equations respectively.

\subsubsection{Time Series Cointegration}

Vector Autoregressive (VAR) model is the estimation method of the Vector Error Correction Model (VECM) is the would be used with $\mathrm{k}$ explicative variables to specify the nature of the VECM. This is the second step in this paper to testing the multivariate co-integration between time series in the analyzing process, if the Co integrated variables are disturbed then will not move apart from each other and as a consequence, capture relationship in a long run base relationship. The Johansen $(1991,1988)$ maximum likelihood test is employ here to examine the cointegration among the variables. The test procedure of the test is follows: Considering the VAR model of order $\mathrm{k}$ :

$$
Y_{t}=\alpha+\Delta_{1} Y_{t-1}+\ldots \ldots \ldots \ldots+\delta_{i} \Delta Y_{t-1}+\varepsilon_{t}
$$

$Y_{t}$ refer to $5 \mathrm{x} 1$ vector of the first order integrated variables, $\varepsilon_{t}$ represent innovation vector. The VAR model can be rewrite as follows: 


$$
\Delta Y_{t}=\alpha+\lambda Y_{t-1}+\sum_{i-1}^{q-1} \pi_{i} \Delta Y_{t-1}+\varepsilon_{t}
$$

Where $\Pi=\sum_{i-1}^{q} \Lambda_{t-1}$ and $\lambda_{i}=-\sum_{J=i+1}^{q} \Lambda_{J}$

Johansen $(1988,1989)$ and also Johansen and Juselius (1990) from the residual vectors propose two statistic tests; the trace test ( $\chi$ trace) the first one to tests the null hypotheses that represent as follows:

$$
\lambda_{\text {trac }(r)}=-T \sum_{J=i+1}^{N} \operatorname{Ln}\left(1-\lambda_{J}\right)
$$

Where $\mathrm{T}$ refer to the number of observations, and $\lambda_{r}$ smallest estimated Eigen values:

\subsubsection{Granger Causality Test}

In order to examine causal relationship between bank credit and the economic growth is Granger Causality test (Granger, 1986), and The Granger Causality test in the contest of VAR framework formulates:

$$
\begin{aligned}
& G D P_{t}=\alpha_{0}+\sum_{i=1}^{p} \alpha_{1 t} G D P_{t-1}+\sum_{i=1}^{q} \alpha_{2 t} T B C_{t-1}+\sum_{i=1}^{m} \alpha_{3 t} C F A_{t-1}+\sum_{i-1}^{n} \alpha_{4 t} C F I_{t-1}+\sum_{i-1}^{s} \alpha_{5 t} C F C_{t-1}+\sum_{i-1}^{t} \alpha_{6 t} C F T_{t-1}+\varepsilon_{1 t} \\
& T B C_{t}=\beta_{0}+\sum_{i=1}^{p} \beta_{1 t} T B C_{t-1}+\sum_{i=1}^{q} \beta_{2 t} G D P_{t-1}+\sum_{i=1}^{m} \beta_{3 t} C F A_{t-1}+\sum_{i=1}^{n} \beta_{4 t} C F I_{t-1}+\sum_{i-1}^{s} \beta_{5 t} C F C_{t-1}+\sum_{i-1}^{t} \beta_{6 t} C F T_{t-1}+\varepsilon_{2 t} \\
& C F A_{t}=\chi_{0}+\sum_{i=1}^{p} \chi_{1 t} C F A_{t-1}+\sum_{i=1}^{q} \chi_{2 t} T B C_{t-1}+\sum_{i=1}^{m} \chi_{3 t} G D P_{t-1}+\sum_{i=1}^{n} \chi_{4 t} C F I_{t-1}+\sum_{i-1}^{s} \chi_{5 t} C F C_{t-1}+\sum_{i=1}^{t} \chi_{6 t} C F T_{t-1}+\varepsilon_{3 t} \\
& C F I_{t}=\delta_{0}+\sum_{i=1}^{p} \delta_{1 t} C F I_{t-1}+\sum_{i=1}^{q} \delta_{2 t} T B C_{t-1}+\sum_{i=1}^{m} \delta_{3 t} C F A_{t-1}+\sum_{i-1}^{n} \delta_{4 t} G D P_{t-1}+\sum_{i-1}^{s} \delta_{5 t} C F C_{t-1}+\sum_{i-1}^{t} \delta_{6 t} C F T_{t-1}+\varepsilon_{4 t} \\
& C F C_{t}=\varepsilon_{0}+\sum_{i=1}^{p} \varepsilon_{1 t} C F C_{t-1}+\sum_{i=1}^{q} \varepsilon_{2 t} T B C_{t-1}+\sum_{i=1}^{m} \varepsilon_{3 t} C F A_{t-1}+\sum_{i-1}^{n} \varepsilon_{4 t} C F I_{t-1}+\sum_{i-1}^{s} \varepsilon_{5 t} G D P_{t-1}+\sum_{i-1}^{t} \varepsilon_{6 t} C F T_{t-1}+\varepsilon_{5 t} \\
& C F T_{t}=\phi_{0}+\sum_{i=1}^{p} \phi_{1 t} C F T_{t-1}+\sum_{i=1}^{q} \phi_{2 t} T B C_{t-1}+\sum_{i=1}^{m} \phi_{3 t} C F A_{t-1}+\sum_{i=1}^{n} \phi_{4 t} C F I_{t-1}+\sum_{i-1}^{s} \phi_{5 t} G D P_{t-1}+\sum_{i=1}^{t} \phi_{6 t} G D P_{t-1}+\varepsilon_{6 t}
\end{aligned}
$$

The parameters are: $\left(\alpha_{1 t, \ldots, 6 t}, \beta_{1 t, \ldots, 6 t}, \chi_{1 t, \ldots, 6 t}, \delta_{1 t, \ldots, 6 t}, \varepsilon_{1 t, \ldots, 6 t}, \phi_{1 t, \ldots, 6 t}\right)$.

This test enables us to determine the causality direction existing between the variables of our study, and it may detect the relationship of unidirectional causality, no causality and bidirectional between the variables under investigation. If statistically significant the parameters of the lagged variables. In last 6 equations for the variable of our study it suggests for a causality relationship. Otherwise, no causal relationship.

\section{Empirical Results}

We started our investigation by checking the stationarity for every individual time series in the study. We employ two unit root tests (ADF), and (PP) tests. The results of thses tests indicate for none of the series in levels can be reject the null hypothesis at 5\% level of significance, but for the first differences we reject the null hypothesis at 5\% level of significance. We can conclude that all time series for the variables under study of order one, I(1) are integrated. 
Table 1. Represent Unit Root tests

\begin{tabular}{cccccc}
\hline \multirow{2}{*}{ Variables } & \multicolumn{2}{c}{ ADF Test } & \multicolumn{2}{c}{ PP Test } & \multirow{2}{*}{ Inference } \\
\cline { 2 - 5 } & Level & Difference & Level & Difference & \\
\hline RGDP & 4.19 & $-8.728^{*}$ & 3.63 & $-12.08^{*}$ & $\mathrm{I}(1)$ \\
\hline TBC & 1.77 & $-3 . .10^{* *}$ & 2.31 & $-5.26^{* *}$ & $\mathrm{I}(1)$ \\
\hline CFA & -0.541 & $-6.22^{*}$ & -0.377 & $-9.316^{*}$ & $\mathrm{I}(1)$ \\
\hline CFI & 1.72 & $-3.11^{* *}$ & 2.29 & $-5.22^{*}$ & $\mathrm{I}(1)$ \\
\hline CFC & 3.12 & $-2.98^{* *}$ & 3.10 & $-5.86^{*}$ & $\mathrm{I}(1)$ \\
\hline CFT & 1.28 & $-4.15^{*}$ & 1.25 & $-10.23^{*}$ & $\mathrm{I}(1)$ \\
\hline
\end{tabular}

- *,** refer to the rejection of the null hypothesis at the level of significance $1 \%$, and $5 \%$.

Note: RGDP refer to the real gross domestic product, TBC is Total bank credit facilities for all sectors, CFA is Bank credit facilities for agriculture sector, CFI is Bank credit facilities for industry sector, CFC is Bank credit facilities for construction sector, CFT is Bank credit facilities for tourism sector.

\section{Johansen Co-integration Results}

It is well recognized that the sensitivity of Johansen's co integration tests are very high to the option of lag length. In order discover the appropriate lag structure the VAR model is adjusted to the time series data. For those nonstationary variables with the same order are integrated Johansen Co-integration tests can be only utilized, and through our investigation the results confirms that all six variables were found as I(1). In our suggested model dependent variable is RGDP while, TBC, CFA, CFI, CFC, and CFT are independent variables.

In this paper we have three hypotheses according to the Johansen test. "The first null hypothesis declares that there are no cointegration vectors through study variables, the second alternative hypothesis declares that the number of co-integration vectors is less than or equal to one, and the third one hypothesis is that: co-integration vectors are at most two". Batarseh, A. \& Ananzeh, I. (2015).

Table 2. Johansen Cointegration tests

\begin{tabular}{|c|c|c|c|c|c|c|c|c|}
\hline $\begin{array}{l}\text { Hypothesized } \\
\text { No. of CE(s) }\end{array}$ & $\begin{array}{l}\text { Eigen } \\
\text { value }\end{array}$ & Statistic & $\begin{array}{l}\text { Critical } \\
\text { Value } \\
5 \%\end{array}$ & Prob.** & $\begin{array}{l}\text { Max Eigen } \\
\text { value }\end{array}$ & Statistic & $\begin{array}{l}\text { Critical } \\
\text { Value } \\
1 \%\end{array}$ & Prob.** \\
\hline None * & 0.44 & 78.44 & 47.86 & 0.00 & 0.44 & 46.49 & 27.58 & 0.00 \\
\hline At most $1 *$ & 0.23 & 31.95 & 29.80 & 0.03 & 0.23 & 20.48 & 21.13 & 0.06 \\
\hline At most 2 & 0.11 & 11.46 & 15.49 & 0.18 & 0.11 & 8.84 & 14.26 & 0.30 \\
\hline At most 3 & 0.03 & 2.62 & 3.84 & 0.11 & 0.03 & 2.62 & 3.84 & 0.11 \\
\hline At most 4 & 0.079 & 8.20 & 15.41 & 0.14 & 0.079 & 8.201 & 20.04 & 0.14 \\
\hline At most 5 & 0.018 & 1.5123 & 3.76 & 0.24 & 0.018 & 1.512 & 6.65 & 0.24 \\
\hline
\end{tabular}

Note: $* \& * *$ : Indicate to the Statistical significance at $5 \%$ and $1 \%$, respectively.

According to the co integration results presented in Table 2 stated for the first hypothesis that the trace statistics at alpha $1 \%$ are greater than critical value. Therefore at this level we can reject the first null hypothesis that indicates one co-integrating vector at least, and the thus the a long run relationship could be deduced between real RGDP and its independent variables of TBC, CFA, CFI, CFC, and CFT in our country.

\section{Error Correction Model Results}

The ECM helping us to recognizing between the long run and short run Granger causality. Long run relationship through the study variables represented by the Error Correction Model. 
Table 3 reports the results of level equation and ECM. In our paper we run the test for different lag level until 3 lags, and we can see the short term co-efficient in this table. Short term co-efficient of CFA, CFC, and CFT at $\alpha$ levels are not statistically significant, also short term co-efficient of DS are not statistically significant in general but only at lag 3 , short term effect of RGDP, TBC, and CFI are statistically significant at $\alpha=0.05$ which means that if TBC increases by $1 \%$, RGDP of Jordan economy increases by $0.10355 \%$ in the short term, and if CFI increases by $1 \%$, RGDP of Jordan increases by $0.0812 \%$ in the short term.

\begin{tabular}{|c|c|}
\hline \multirow{2}{*}{\multicolumn{2}{|c|}{ Date: 12/29/15 Time: 11:33 }} \\
\hline & \\
\hline \multicolumn{2}{|c|}{$\begin{array}{l}\text { Included observations: } 81 \text { after adjusting } \\
\text { endpoints }\end{array}$} \\
\hline \multicolumn{2}{|c|}{ Standard errors \& t-statistics in parentheses } \\
\hline Co integrating Eq: & CointEq1 \\
\hline RGDP(-1) & 1 \\
\hline \multirow[t]{3}{*}{ TBC(-1) } & 81.21016 \\
\hline & 143.074 \\
\hline & 0.56761 \\
\hline \multirow[t]{3}{*}{ CFA(-1) } & -1.835978 \\
\hline & -3.21305 \\
\hline & $(-0.57141)$ \\
\hline \multirow[t]{3}{*}{ CFI(-1) } & -78.90173 \\
\hline & -138.274 \\
\hline & $(-0.57062)$ \\
\hline \multirow[t]{3}{*}{ CFC(-1) } & -2.636032 \\
\hline & -4.15661 \\
\hline & $(-0.63418)$ \\
\hline \multirow[t]{3}{*}{ CFT(-1) } & 0.618964 \\
\hline & -1.26705 \\
\hline & -0.48851 \\
\hline
\end{tabular}

\begin{tabular}{lcrrrrr}
\hline Error Correction: & $\mathrm{D}(\mathrm{RGDP})$ & $\mathrm{D}(\mathrm{TBC})$ & $\mathrm{D}(\mathrm{CFA})$ & $\mathrm{D}(\mathrm{CFI})$ & $\mathrm{D}(\mathrm{CFC})$ & $\mathrm{D}(\mathrm{CFT})$ \\
\hline CointEq1 & & & & & & \\
\hline & 0.052165 & 0.002604 & 0.006173 & 0.002488 & 0.014435 & 0.012141 \\
\hline & 0.0065 & 0.00451 & -0.01449 & 0.00439 & -0.00526 & -0.01533 \\
\hline $\mathrm{D}(\mathrm{RGDP}(-1))$ & 8.0312 & -0.5773 & -0.42587 & 0.56738 & -2.74499 & -0.79191 \\
\hline & & & & & & \\
\hline & -0.839222 & 0.152753 & 0.12934 & 0.107424 & 0.049815 & -0.23623 \\
\hline $\mathrm{D}(\mathrm{RGDP}(-2))$ & -0.09012 & 0.04258 & -0.2011 & -0.06085 & -0.07297 & -0.21272 \\
\hline & $(-9.31206)$ & 1.64182 & -0.64315 & -1.76536 & -0.68271 & $(-1.1154)$ \\
\hline & & & & & & \\
\hline & -0.872768 & 0.036596 & 0.110541 & 0.037635 & 0.108863 & 0.042041 \\
\hline & -0.05662 & 0.03932 & -0.12635 & 0.03823 & 0.04584 & -0.13365 \\
\hline & $(-15.4136)$ & -0.93068 & -0.87486 & 0.98437 & -2.37463 & -0.31456 \\
\hline
\end{tabular}




\begin{tabular}{|c|c|c|c|c|c|c|}
\hline $\mathrm{D}(\operatorname{RGDP}(-3))$ & -0.731945 & 0.166404 & 0.221517 & 0.170556 & 0.128988 & 0.101452 \\
\hline & -0.07535 & -0.05233 & -0.16814 & -0.05088 & -0.06101 & -0.17786 \\
\hline & $(-9.71372)$ & -3.18005 & -1.31742 & -3.35225 & -2.11431 & -0.57042 \\
\hline \multirow[t]{3}{*}{$\mathrm{D}(\mathrm{TBC}(-1))$} & 0.10355 & 0.870383 & -5.06288 & 1.349612 & 0.083062 & -0.88854 \\
\hline & 0.040512 & -1.948 & -6.25953 & -1.89404 & -2.27112 & -6.62107 \\
\hline & $(0.49233)$ & -0.44681 & $(-0.8083)$ & -0.71256 & -0.03657 & $(-0.1340)$ \\
\hline \multirow[t]{3}{*}{$\mathrm{D}(\mathrm{TBC}(-2))$} & -0.349777 & -1.68141 & -5.65358 & -1.44073 & -2.10203 & -5.68989 \\
\hline & 0.05616 & -2.12233 & -6.81971 & -2.06354 & -2.47437 & -7.21361 \\
\hline & $(0.11445)$ & $(-0.7925)$ & $(-0.8201)$ & $(-0.6918)$ & $(-0.8452)$ & $(-0.7877)$ \\
\hline \multirow[t]{3}{*}{$\mathrm{D}(\mathrm{TBC}(-3))$} & -2.318673 & -0.99943 & -1.79876 & -0.88006 & 1.474077 & -9.74357 \\
\hline & 0.81778 & -1.95679 & -6.28778 & -1.90259 & -2.28137 & -6.65095 \\
\hline & $(0.82287)$ & $(-0.5105)$ & $(-0.2867)$ & $(-0.4626)$ & -0.64614 & $(-1.4699)$ \\
\hline \multirow[t]{3}{*}{$\mathrm{D}(\mathrm{CFA}(-1))$} & 0.019312 & 0.03604 & -0.01695 & -0.02755 & 0.048912 & 0.014093 \\
\hline & $(0.07675)$ & -0.04929 & -0.15839 & -0.04793 & -0.05747 & -0.16754 \\
\hline & $(0.25162)$ & $(-0.7312)$ & $(-0.1069)$ & $(-0.5740)$ & -0.85113 & -0.08412 \\
\hline \multirow[t]{3}{*}{$\mathrm{D}(\mathrm{CFA}(-2))$} & 0.081220 & 0.003409 & -0.08603 & 0.004454 & 0.013418 & 0.057682 \\
\hline & $(0.07439)$ & -0.0498 & -0.16001 & -0.04842 & -0.05806 & -0.16925 \\
\hline & $(1.09175)$ & -0.06846 & $(-0.5364)$ & -0.092 & -0.23113 & -0.34081 \\
\hline \multirow[t]{3}{*}{$\mathrm{D}(\mathrm{CFA}(-3))$} & 0.118945 & -0.0366 & -0.28718 & -0.03749 & 0.034394 & -0.00577 \\
\hline & -0.069 & -0.04792 & -0.15397 & -0.04659 & -0.05586 & -0.16286 \\
\hline & -1.72385 & $(-0.7638)$ & $(-1.8658)$ & $(-0.8462)$ & -0.61566 & $(-0.0355)$ \\
\hline \multirow[t]{3}{*}{$\mathrm{D}(\mathrm{CFI}(-1))$} & -0.019316 & -0.02707 & -0.05022 & -0.01981 & 0.01279 & 0.09459 \\
\hline & 0.07675 & 0.05108 & 0.16589 & 0.04942 & 0.06025 & 0.17000 \\
\hline & -0.251624 & -0.52987 & -0.30274 & -0.39823 & 0.20056 & 0.55562 \\
\hline \multirow[t]{3}{*}{$\mathrm{D}(\mathrm{CFI}(-2))$} & 0.081210 & 0.00538 & -0.10537 & 0.00602 & -0.01129 & 0.07938 \\
\hline & 0.034390 & 0.04951 & 0.16079 & 0.04821 & 0.05885 & 0.16478 \\
\hline & 1.0917 & 0.10867 & -0.6554 & 0.12503 & -0.19183 & 0.48178 \\
\hline \multirow[t]{3}{*}{$\mathrm{D}(\mathrm{CFI}(-3))$} & 2.051818 & 1.095246 & 1.379834 & 0.961223 & -1.48844 & 9.270503 \\
\hline & -2.83388 & -1.96797 & -6.3237 & -1.91346 & -2.29441 & -6.68895 \\
\hline & -0.72403 & -0.55654 & -0.2182 & -0.50235 & $(-0.6483)$ & -1.38594 \\
\hline \multirow[t]{3}{*}{$\mathrm{D}(\mathrm{CFC}(-1))$} & -0.233319 & 0.066089 & -0.3732 & 0.056927 & 0.113695 & -0.98874 \\
\hline & -0.15329 & -0.10645 & -0.34207 & -0.1035 & -0.12411 & -0.36182 \\
\hline & $(-1.52205)$ & -0.62083 & $(-1.0901)$ & -0.55 & -0.91608 & $(-2.7365)$ \\
\hline \multirow[t]{3}{*}{$\mathrm{D}(\mathrm{CFC}(-2))$} & 0.231486 & -0.0241 & 0.276439 & -0.01833 & -0.03014 & 0.116967 \\
\hline & -0.14408 & -0.10005 & -0.32151 & -0.09728 & -0.11665 & -0.34008 \\
\hline & -1.60666 & $(-0.2402)$ & -0.85982 & $(-0.1881)$ & $(-0.2534)$ & -0.34394 \\
\hline $\mathrm{D}(\mathrm{CFC}(-3))$ & 0.199628 & 0.057068 & -0.06225 & 0.0578 & 0.153599 & 0.333672 \\
\hline
\end{tabular}




\begin{tabular}{|c|c|c|c|c|c|c|}
\hline & -0.11723 & -0.08141 & -0.2616 & -0.07916 & -0.09491 & -0.27671 \\
\hline & -1.70285 & -0.70099 & $(-0.2375)$ & -0.7302 & -1.61828 & -1.20587 \\
\hline \multirow[t]{3}{*}{$\mathrm{D}(\mathrm{CFT}(-1))$} & 0.15245 & 0.04951 & 0.033322 & 0.049366 & 0.012627 & 0.015285 \\
\hline & -0.05203 & -0.03613 & -0.1161 & -0.03513 & -0.04212 & -0.12281 \\
\hline & -2.9301 & -1.37028 & -0.28701 & -1.40522 & -0.29976 & -0.12446 \\
\hline \multirow[t]{3}{*}{$\mathrm{D}(\mathrm{CFT}(-2))$} & 0.160638 & -0.05353 & 0.224476 & -0.05038 & -0.04175 & 0.108072 \\
\hline & -0.05121 & -0.03556 & -0.11427 & 0.03458 & -0.04146 & -0.12087 \\
\hline & -3.13698 & $(-1.5058)$ & -1.96446 & $(-1.4572)$ & $(-1.0069)$ & -0.89413 \\
\hline \multirow[t]{3}{*}{$\mathrm{D}(\mathrm{CFT}(-3))$} & 0.106362 & -0.01032 & -0.08644 & -0.01026 & -0.07479 & 0.209807 \\
\hline & -0.04941 & -0.03431 & -0.11025 & -0.03336 & -0.04 & -0.11662 \\
\hline & -2.1527 & $(-0.3062)$ & $(-0.7841)$ & $(-0.3078)$ & $(-1.8695)$ & -1.79904 \\
\hline R-squared & 0.890142 & 0.443012 & 0.251553 & 0.458342 & 0.545413 & 0.185282 \\
\hline Adj. R-squared & 0.858248 & 0.281306 & 0.034263 & 0.301087 & 0.413436 & -0.05125 \\
\hline Sum sq. resids & 0.009759 & 0.004706 & 0.048595 & 0.004449 & 0.006397 & 0.054371 \\
\hline S.E. equation & 0.012546 & 0.008713 & 0.027996 & 0.008471 & 0.010158 & 0.029613 \\
\hline F-statistic & 27.9092 & 2.739609 & 1.157681 & 2.914637 & 4.132635 & 0.783332 \\
\hline Log likelihood & 250.5377 & 280.0739 & 185.5224 & 282.3493 & 267.6427 & 180.9741 \\
\hline Akaike AIC & -5.716981 & -6.44627 & -4.11166 & -6.50245 & -6.13933 & -3.99936 \\
\hline Schwarz SC & -5.15532 & -5.88461 & -3.55 & -5.94079 & -5.57767 & -3.4377 \\
\hline Mean dependent & 0.009802 & 0.00958 & 0.006494 & 0.009531 & 0.010358 & 0.014444 \\
\hline S.D. dependent & 0.033323 & 0.010277 & 0.028489 & 0.010133 & 0.013263 & 0.028883 \\
\hline \multicolumn{7}{|l|}{ Determinant Residual } \\
\hline Covariance & & $3.64 \mathrm{E}-26$ & & & & \\
\hline Log Likelihood & & 1682.663 & & & & \\
\hline Akaike Information Criteria & & -38.5843 & & & & \\
\hline Schwarz Criteria & & -35.0369 & & & & \\
\hline
\end{tabular}

Table 3 reports that ECT is $5.216 \%$, positively and statistically significant at level $\alpha 1 \%$, figure 0.05216 display that the short run values of RGDP converging to its long run Equilibrium level by $5.216 \%$ adjustment speed every year through the CFA, CFC, and CFT contributions.

We can see from the figures of level Equation when CFA increasing by 0.01, then the GDP increasing by $0.0193 \%$ and its statistically significant at $\alpha=0.10$.

\section{The results of Granger Causality Tests}

After the process of analyzing the co-integration and ECM, and our results supports that co-integration vectors found between our study variables. In this time we must applied the Granger Causality Test.

Table 4 reports the outcomes of the test, the outcomes presents that there is a single causality running from CFC to CFA, from CFI to CFA, from CFT to CFA, from CFA to CFT, from RGDP to CFA from TBC to CFA, from CFI to CFC, from RGDP to CFC, from CFC to RGDP, from TBC to CFC, and from TBC to CFI. Also in Table 4, the bidirectional causality observed among variables CFT, CFA, and RGDP, CFC. 


\begin{tabular}{|c|c|c|c|}
\hline \multicolumn{4}{|l|}{ Pairwise Granger Causality Tests } \\
\hline Date: $12 / 29 / 15 \quad$ Time: $17: 54$ & & & \\
\hline \multicolumn{4}{|l|}{ Sample: 185} \\
\hline \multicolumn{4}{|l|}{ Lags: 3} \\
\hline Null Hypoth: & Obs & F-Stat & Prob \\
\hline CFC doesn't Granger Cause CFA & 82 & 2.8394 & 0.04357 \\
\hline CFA doesn't Granger Cause CFC & & 0.4723 & 0.70247 \\
\hline CFI doesn't Granger Cause CFA & 82 & 3.5131 & 0.0192 \\
\hline CFA doesn't Granger Cause CFI & & 2.0487 & 0.11426 \\
\hline CFT doesn't Granger Cause CFA & 82 & 2.2279 & 0.09188 \\
\hline CFA doesn't Granger Cause CFT & & 2.733 & 0.04961 \\
\hline RGDP doesn't Granger Cause CFA & 82 & 3.2034 & 0.02797 \\
\hline CFA doesn't Granger Cause RGDP & & 1.0337 & 0.38267 \\
\hline TBC doesn't Granger Cause CFA & 82 & 3.4937 & 0.01966 \\
\hline CFA doesn't Granger Cause TBC & & 1.7941 & 0.15557 \\
\hline CFI doesn't Granger Cause CFC & 82 & 2.8818 & 0.04138 \\
\hline CFC doesn't Granger Cause CFI & & 1.5488 & 0.20893 \\
\hline CFT doesn't Granger Cause CFC & 82 & 0.9617 & 0.4154 \\
\hline CFC doesn't Granger Cause CFT & & 2.1137 & 0.10557 \\
\hline RGDP doesn't Granger Cause CFC & 82 & 7.0109 & 0.00032 \\
\hline CFC doesn't Granger Cause RGDP & & 2.2266 & 0.09202 \\
\hline TBC doesn't Granger Cause CFC & 82 & 3.1977 & 0.02816 \\
\hline CFC doesn't Granger Cause TBC & & 1.6139 & 0.19327 \\
\hline CFT doesn't Granger Cause CFI & 82 & 1.901 & 0.13669 \\
\hline CFI doesn't Granger Cause CFT & & 2.1034 & 0.10691 \\
\hline RGDP doesn't Granger Cause CFI & 82 & 1.6004 & 0.19642 \\
\hline CFI doesn't Granger Cause RGDP & & 12.724 & $8.30 \mathrm{E}-07$ \\
\hline TBC doesn't Granger Cause CFI & 82 & 2.5949 & 0.05872 \\
\hline CFI doesn't Granger Cause TBC & & 1.9122 & 0.13485 \\
\hline RGDP doesn't Granger Cause CFT & 82 & 1.2899 & 0.2841 \\
\hline CFT doesn't Granger Cause RGDP & & 0.9402 & 0.42564 \\
\hline TBC doesn't Granger Cause CFT & 82 & 2.0735 & 0.11087 \\
\hline CFT doesn't Granger Cause TBC & & 2.0681 & 0.11159 \\
\hline TBC doesn't Granger Cause RGDP & 82 & 12.283 & $1.30 \mathrm{E}-06$ \\
\hline RGDP doesn't Granger Cause TBC & & 1.5568 & 0.20696 \\
\hline
\end{tabular}




\section{Conclusion}

The Jordanian economy had suffered from many unstable political events from near country that hampered its growth for several periods from the year of 1990. Over and above of poor provision of infrastructure, especially the financing of different vital sectors could be one of the main factors of slow growth. So that this study came to study the relation between bank credit for different sectors and economic growth through employing different advanced methodologies VECM, and Granger Causality Test, and using quarterly data for the period 1993-2014.

The empirical analysis proposed that variables that determine bank credit for different sectors and RGDP present a unit root. Once a co integrated relationship among relevant economic variables is established. The results of this study report for a long run relationship could be inferred between real RGDP and its Explanatory variables of TBC, CFA, CFI, CFC, and CFT in our country. So we can suggest that TBC, CFA, CFI, CFC, and CFT are in the long term equilibrium relationship with the economic development in Jordan.

The Granger causality test report that causality runs from economic development, measured as bank credit for agriculture and construction sectors in Jordan economy. The results report bidirectional causality observed among economic development and bank credit to construction Overall, the underdevelopment of credit and stock markets with no financial depth remains one of the main obstacles faced this economy.

As a result, banking with different sectors has played a positive role in enhancing the growth of the Jordanian economy. furthermore, more rehabilitation of the financial sector enhance the opportunity for economic growth.

We recommend in this study to bring attention the government of Jordan toward the role of intermediation markets that can reduce financial sector instability that could spoil growth in the future, and we recommend for further study in the future in the same contest.

\section{References}

Abu-Bader, S., \& Abu-Qarn, A. (2007). Financial Development and Economic Growth. The Egyptian Experience. Journal of Policy Modeling, 30(5), 887-898. http://dx.doi.org/10.1016/j.jpolmod.2007.02.001

Baliamoune, L. (2008). Financial development and income. International Advances in Economic Research, 14, 422-432. http://dx.doi.org/10.1007/s11294-008-9176-5

Batarseh, A., \& Ananzeh, I. (2015). The Causal Relationship among Foreign Direct Investment, Domestic Saving and Economic Growth in Jordan during the Period (1975-2013). International Journal of Business and Management, 10(1). http://dx.doi.org/10.5539/ijbm.v10n1p73

Bayoumi, T., \& Ola, M. (2008). Credit matters: Empirical Evidence on U.S. Macro Financial Linkages, IMF Working Paper No. WP/08/169, July.

Ben Salem, J. B., \& Trabelsi, M. (2012). More on finance and growth in the MENA region: more growth, more finance. Middle Eastern Finance and Economics, 17, 113-124.

Bencivenga, V., \& Bruce, S. (1991). Financial Intermediation and Endogenous Growth. Review of Economic Studies, 1991, 195-209. http://dx.doi.org/doi: 10.2307/2297964

Demetriades, P. O., \& Hussein, K. A. (1996). Does financial development cause economic growth? time-series evidence from 16 countries. Journal of Development Economics, 51(2), 387-411. http://dx.doi.org/10.1016/S0304-3878(96)00421-X

Dickey, D. A., \& Fuller, W. A. (1979). Disiribution of the estimators for autoregressive lime sdries with a unit root. Journal of the American Stattitical Association, 74, 427-31. http://dx.doi.org/10.2307/2286348

Eatzaz, A., \& Fuller, M. A. (2009). Financial Sector and Economic Growth: An Empirical Analysis of Developing Countries. Journal of Economic Cooperation and Development, 30(1), 17-40.

Goldsmith, R. (1969). Financial Structure and Development. Yale University Press, New Haven, Ct.

Gurley, J. G., \& Shaw, E. S. (1960). Money in a Theory of Finance. Brookings Institution. Washington D.C.

Gurly, J., \& Shaw, E. (1967). Financial structure and economic growth. Economics Development and Culture Change, 34, 333-346.

Johansen, S. (1988). Statistical Analysis of Cointegration Vectors. Journal of Economic Dynamics and Control, 12, 231-4. http://dx.doi.org/10.1016/0165-1889(88)90041-3 
Johansen, S. (1991). Estimation and Hypothesis Testing of Cointegration Vectors in Gaussian Vector Autoregressive Models. Econometrica, 55, 1551-80. http://dx.doi.org/10.2307/2938278

Johansen, S., \& Juselius, K. (1990). Maximum Likelihood Estimation and Inference on Cointegration: with Application to the Demand for Money. Oxford Bulletin of Economics and Statistics, 52, 169-210. http://dx.doi.org/10.1111/j. 1468-0084.1990.mp52002003.x

Kar, M., \& Pentecost, E. J. (2000). Financial Development and Economic Growth in Turkey: Further Evidence on the Causality Issue. Economic Research Paper No. 00/27.

Kar, M., Nazilioglu, S., \& Agir, H. (2011). Financial Development and Economic Growth Nexus in the MENA Countries: Bootstrap Panel Granger Causality Analysis. Economic Modelling, 28, 685-693.

Kasekende, L. (2008). Developing a Sound Banking System. Paper presented at IMF Seminar, Tunisia.

King, R. G., \& Levine, R(1993). Finance and Growth: Schumpeter Might Be Right. Quarterly Journal of Economics, 108(3), pp. 717-37. http://dx.doi.org/10.1016/0304-3932(93)90028-E,

Phillips. P. C., \& Perron, B. P.(1988). Testing for a unit root in time series regression. Bhmetrika, 75(335), 6. http://dx.doi.org/10.1093/biomet/75.2.335

Robinson, J. (1952). The Generalization of the General Theory. In The Rate of Interest and Other Essays (pp. 67146). London: McMillan.

Schumpeter, J. (1911). Theorie der wirtschaftlichen Entwicklung. Trans. Markus C. Becker and Thorbjorn Knudsen. American Journal of Economics and Sociology, 61(2), 406-37.

Shaw, E. (1973). Financial deepening in economic development. New York, Oxford University Press.

Spellman, L. J. (1982). The Depository Firm and Industry: Theory, History, and Regulation. Academic Press, Inc. 